\title{
Learning Grammar of a Foreign Language (English) using Multimedia Technologies
}

\author{
${ }^{1}$ Alla Hovorun, ${ }^{2}$ Olena Petukhova, ${ }^{3}$ Olena Nazymko, ${ }^{4}$ Tetiana Kyrychenko, ${ }^{5}$ Iryna Bodnar, ${ }^{6}$ Oleksandra Kanyuk \\ ${ }^{1,2}$ Faculty of Environmental Design, Department of Pedagogy, Ukrainian and Foreign Philology, Kharkiv State \\ Academy of Design and Arts, Kharkiv, Ukraine \\ ${ }^{3}$ Foreign Languages Department, O.M.Beketov National University of Urban Economy in Kharkiv, Ukraine \\ ${ }^{4}$ Faculty of Biology and Technology, Department of Foreign Languages, Sumy National Agrarian University \\ Sumy, Ukraine \\ ${ }^{5}$ Faculty of Foreign Languages, Department of Foreign Languages for Sciences, Ivan Franko National University \\ of Lviv, Ukraine \\ ${ }^{6}$ Faculty of Foreign Philology, Department of Foreign Languages, Uzhhorod National University, Uzhhorod,
} Ukraine

Received: August 4, 2021. Revised: September 8, 2021. Accepted: September 10, 2021. Published: September 14, 2021.

\begin{abstract}
Exploring ways of learning foreign language grammar using video content in secondary education is relevant because most research focuses on other educational levels and rarely takes into account student and teacher assessments. In addition, the vast majority of studies deal with the theoretical aspects of foreign language grammar learning at school. Accordingly, there is a need for empirical studies that focus more on secondary education and the nature of teachers and students' perceptions of such issues. This determined the relevance of the article. The aim of the study is to establish the effectiveness of the use of audiovisual materials as a tool for learning a foreign language. As a result, was determined the assessment of teachers and students' feasibility of introducing video content in the process of learning grammar of a foreign (English) language. The main methods in the study were methods of experiment and interviewing; also, the method of questioning was used. The main hypothesis is that the introduction of video content as teaching material for learning foreign languages is an effective method of teaching, positively evaluated by all participants in the educational process. The results of the study show that the introduction of films as teaching material in the educational process contributes to the teacher's willingness to use video content for their lessons, the understanding of all participants in the educational process of the benefits of using audio-visual materials is improved; the performance increases. Increasing the level of methodological skill and awareness gained through personal experience encourages improvement of the learning process, awareness of the need to use the completely rich arsenal of modern methods and forms of language teaching. In the future perspective is the study
\end{abstract}

that the use of audio-visual content as didactic material is not only a means of learning a language, but also a factor in improving critical thinking skills, a sense of social justice, awareness of art, in particular, history of the culture.

Keywords - audiovisual technologies, foreign language teaching, higher education, pedagogics, techniques of teaching, video resources.

\section{INTRODUCTION}

$\mathrm{T}$ he problem of establishing the appropriateness of the use of educational technology is related to the issue of strategies for the presentation and reproduction of various forms of educational information. It all is related to the search for effective ways of transferring knowledge, expediency of using modern educational technologies. Description and formalization of educational technologies of pedagogical activity contributes to the ability to reproduce the successful educational experience. Therefore, it is relevant to the constant introduction of empirical research to the implementation of innovations in the modern school.

Audiovisual materials (documentaries, animated and feature films, television shows, TV series) have been very useful for use in foreign language lessons, as evidenced by a number of contemporary studies [1]. Specialists have focused on various communication channels that can be used to learn foreign languages: the Facebook community [2], a variety of gadgets, the use of video games and testing. Many theoretical studies have been conducted in this area [3]. Accordingly, evidence that is more empirical is needed to prove or disprove the theory of certain benefits of video content use [4]. Research has focused on perceptions and assessments of student achievement in educational contexts, and the benefits of using 
films for foreign language lessons have not been sufficiently investigated [4]. The mechanisms and factors of introducing video content into the learning process, which is an auxiliary means of reinforcing learned material, and the reasons for using video content as a peripheral element in the classroom, used systematically, without a specific pedagogical purpose [5], according to [6] teachers do not use the full potential of visual materials as part of the language teaching strategy, usually films are used to fill time, entertain and reward students. This research will focus on the implementation of audiovisual technology as part of a pedagogical teaching strategy and should be widely used in foreign language teaching, but not be random and arbitrary. Video content is a modern medium, should be used as a teaching method, movies are accessible and effective teaching resources.

Audiovisual technology is a term that defines a set of operations of methods and techniques built on the use of video resources, which serves to the formation of competence [7]. Such technology relies on the existence of communicative channels in human perception, accept and well assimilate audio and video materials, educational information. This allows making the learning process more effective, and the perception of the material passes with the maximum benefit. Video resources allow presenting the object of foreign language learning in real conditions of its use [8]. Such opportunities have a good job in mastering such a complex section of language as grammar, where language constructions and forms not only demonstrate the language categories themselves, but also all the environments, situations and scenarios in which these forms are implemented. The use of video content to study the grammar of a foreign language is relevant and determines the scientific problems of a number of modern studies.

So far, insufficient attention has been paid to the attitude of teachers towards conducting English lessons with the use of films.

\section{AIMS}

The aim of the study is to establish the effectiveness of the introduction of audiovisual materials for the study of grammar in English lessons. Based on the goal it is planned to perform the following research tasks:

- to establish how the introduction of video content to teaching affects the success in learning English;

- to determine the extent to which teachers consider it advisable to introduce systematic video content in the process of studying English grammar;

- to establish how students assess the use of video content for studying English grammar.

\section{LITERATURE REVIEW}

The literature review shows that in the first positions the thesis about the benefits and importance of introducing modern means of communication in the learning process: working with computer games, digital technologies [9]; [10], mobile applications [11], having harmoniously blended into the learning process [12]. This type of learning is useful for society, economy, helps to raise a modern harmonious person.

The study of the features of learning a foreign language with the involvement of new technologies and innovative techniques and their features have been regularly conducted in pedagogy [13]; [7]. The range of issues was wide and problematic, not all methods were effective, and others required the involvement of many resources [14]; [15]. Ways of forming and developing motivation during foreign language learning have been considered [16], activation of intercultural communicative competence in the learning process [16]; [17]. A number of researchers [18]; [2] has investigated modern audiovisual technologies as a tool for foreign language learning. They have also noted that when learning English, students also improve their critical thinking skills when working with video content because they promote selfreflection and the development of their own personality [3]. Visual exposure has been analyzed as a factor in the development of creative skills, students discuss what they see, make assumptions, and analyze images and plot [8]. Stewart, [8] argued that the films itself encourage students to learn English, to understand its structure and features, to form motivation to learn the Ukrainian language. Part of the researchers also considered the problems of developing critical and analytical thinking skills; the student is becoming more and more demanding on the quality of educational content, methodological diversity [19].

Unresolved are the issues of introducing video content to the study of English grammar in school, as would be regular, moderate and effective. In addition, consideration of teacher training in the implementation of audiovisual technology in the educational system and the study of secondary education workers' own vision of the use of modern methods of learning foreign languages requires separate attention.

\section{METHODS}

The research of video content is based on systemic, integrated and technological approaches. Systemic approach means considering audiovisual technology as a system of action, where the experience of the teacher and the needs of the student are taken into account first, i.e. components of the personality sphere. The integrated approach in the study allows us to consider the learning process as non-linear and multidirectional. The integrated approach makes it possible to represent audiovisual technology as an integration of learning and teaching methods, activities, the use of different forms of content and representation of educational information. The technological approach provides for the presentation of the learning process in a sequence of pedagogical operations due to the logic of the pedagogical experiment.

The research data were collected during the academic year 2020/2021 from English language teachers who worked in secondary schools in eastern Ukraine (Kharkov, Zaporizhzhya), where they taught high school classes. All 
teachers (4 people) participants in the experiment had diplomas of teachers of English language and literature, for all teachers the native language was Ukrainian. All of the respondents had from 7 to 14 years of teaching experience and all of them expressed an interest in improving their pedagogical skills, as teachers are frequent attendees of refresher courses and have diplomas of non-formal education.

All the pupils' participants of the experiment are senior pupils (72 people) who studied at secondary schools in Kharkov (Kharkov secondary school № 30, № 133) and Zaporizhzhya (Zaporizhzhya secondary school of I-III levels № 5, and № 76), had experience of learning English. All participants of the experiment voluntarily agreed to take part in the research project. All respondents were provided with anonymity.

The research data was obtained during the implementation of 3 stages of the pedagogical experiment. First, the teachers participating in the experiment were pre-interviewed and also consulted on their readiness and attitude towards using video content in foreign (English) lessons. The teachers and the research team then worked to develop curricula that provided for the active use of films as didactic materials for the course. At the beginning and end of the experiment, testing was conducted and student achievement levels were established. The teachers were also interviewed at the end of the experiment to evaluate the appropriateness of using audiovisual resources in foreign language learning.

\section{RESULTS}

At the preparatory stage (Stage 1) of the pedagogical experiment, the process of planning, organization of the educational process with its subsequent coordination and continuous monitoring of learning outcomes took place, which is the main goal of the group of teachers during the development of new educational technologies. The whole process of conducting the study was planned and divided into stages.

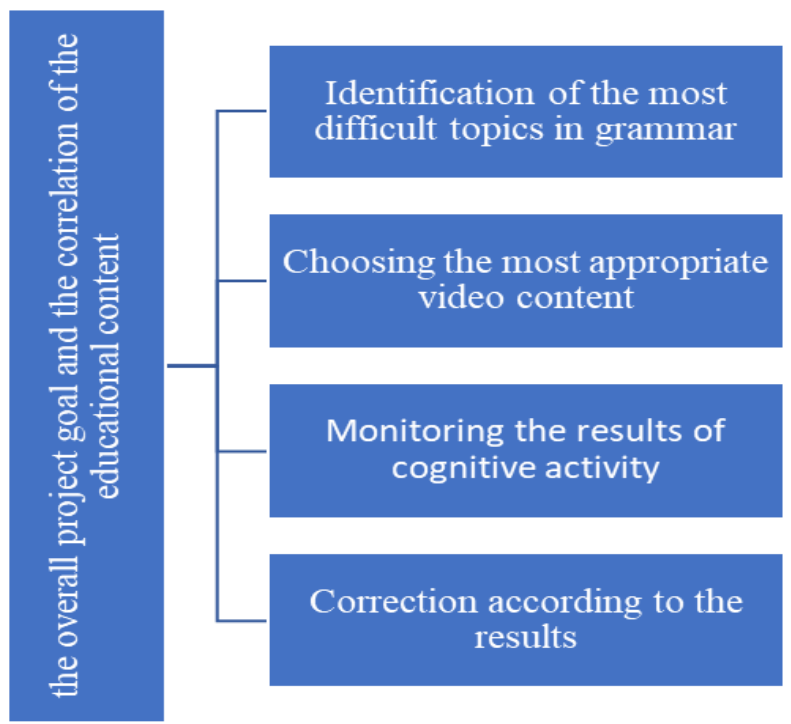

Fig. 1 The main stages of introducing audiovisual technologies to the study of foreign language grammar

At this stage, the research team and teachers selected educational material with the necessary interpretations and explanations for students regarding complex grammatical topics (the use of verb forms, prepositions, articles, suppletive forms, etc.). The video was used not only as an entertainment, but also as an illustrative, educational material for the topics on English grammar.

In addition, at the preliminary stage, all students were grouped (G1, G2 Kharkiv; G3, G4 Zaporizhzhya), and there were 18 people in each group. Then there was a preliminary test of the participants on the level of awareness of English grammar.

Table 1. Preliminary testing for knowledge of English grammar

\begin{tabular}{|l|l|l|l|l|}
\hline & Unsatisfactorily & Satisfactorily & Good & Excellent \\
\hline Group 1 & $18 \%$ & $33 \%$ & $35 \%$ & $14 \%$ \\
\hline Group 2 & $16 \%$ & $32 \%$ & $42 \%$ & $10 \%$ \\
\hline Group 3 & $15 \%$ & $35 \%$ & $39 \%$ & $11 \%$ \\
\hline Group 4 & $16 \%$ & $40 \%$ & $14 \%$ \\
\hline
\end{tabular}

During the 2nd stage of the experiment, active use of video content was introduced in the teaching practice, which was also explained with comments, repetitions of difficult passages and flowcharts. This stage also included a control work 1, which showed the success of the respondents in knowing English grammar. 
Table 2. Test work 1

\begin{tabular}{|l|l|l|l|l|}
\hline & Unsatisfactory & Satisfactory & Good & Excellent \\
\hline Group 1 & $17 \%$ & $32 \%$ & $37 \%$ & $14 \%$ \\
\hline Group 2 & $15 \%$ & $33 \%$ & $40 \%$ & $12 \%$ \\
\hline Group 3 & $15 \%$ & $34 \%$ & $36 \%$ & $14 \%$ \\
\hline Group 4 & $14 \%$ & $28 \%$ & $44 \%$ & $14 \%$ \\
\hline
\end{tabular}

According to the test results, the overall success of students increased by $2 \%$. In groups 2 and 3 , the number of grades increased by $2.5 \%$.

The final stage of the project showed the results of interviews with teachers participating in the experiment.
Teachers were asked a series of questions at the beginning, end of the experiment, and compared their answers

Table 3. The results of teachers interview regarding the attitude to the introduction of video content for English lessons

\begin{tabular}{|l|l|l|l|}
\hline Teacher & Question & Answer to the beginning & Answer at the final stage \\
\hline Teacher 1 & $\begin{array}{l}\text { How do you feel about } \\
\text { using video content? }\end{array}$ & $\begin{array}{l}\text { Positively. I use original English series } \\
\text { 2-3 times per school year due to the lack } \\
\text { of time. }\end{array}$ & $\begin{array}{l}\text { This is good. However, I still } \\
\text { believe that working with a text for } \\
\text { studying grammar is better. }\end{array}$ \\
\hline Teacher 2 & $\begin{array}{l}\text { How do you feel about } \\
\text { using video content? }\end{array}$ & $\begin{array}{l}\text { Positively. This a nice way to break } \\
\text { up the similarity in the study of } \\
\text { grammar. }\end{array}$ & $\begin{array}{l}\text { Effective. It is worth continuing this } \\
\text { experience, increasing the number } \\
\text { of targeted video content on } \\
\text { grammatical topics. }\end{array}$ \\
\hline Teacher 3 & $\begin{array}{l}\text { How do you feel about } \\
\text { using video content? }\end{array}$ & $\begin{array}{l}\text { This is a useful practice. Two times a } \\
\text { year I demonstrate a documentary film. } \\
\text { I ask my pupils to write a short synopsis } \\
\text { about it. }\end{array}$ & $\begin{array}{l}\text { This is good, but I do not think that } \\
\text { watching movies helps you to learn } \\
\text { grammar. }\end{array}$ \\
\hline Teacher 4 & $\begin{array}{l}\text { How do you feel about } \\
\text { using video content? }\end{array}$ & $\begin{array}{l}\text { This is good. I use animation at the } \\
\text { beginning and at the end of the school } \\
\text { year to allow pupils to feel their own } \\
\text { progress. }\end{array}$ & $\begin{array}{l}\text { It was good to work this way. In } \\
\text { addition to reading and speaking, } \\
\text { pupils also listened to the language } \\
\text { and were able to notice their own } \\
\text { mistakes. }\end{array}$ \\
\hline
\end{tabular}

As we can see 1 teacher out of 4 respondents was skeptical about using videos to learn English grammar. One teacher thinks it is necessary to continue to actively use video content to learn the grammar of a foreign language. Others were positive about this practice. At the beginning, the vision for the use of video content was vague and was more about forms of recreation and encouragement. At the end of the project the vision of the purpose of using video in learning grammar, there is an understanding of the need for innovation in the educational process.

At the 3rd (final) stage, a final control was carried out, which allowed us to determine how the performance of the students who took part in the experiment would change, if any.

Table 4. Final test $\# 2$ on the knowledge of English grammar

\begin{tabular}{|l|l|l|l|l|}
\hline & Unsatisfactory & Satisfactory & Good & Excellent \\
\hline Group 1 & $16 \%$ & $30 \%$ & $38 \%$ & $16 \%$ \\
\hline Group 2 & $13 \%$ & $32 \%$ & $40 \%$ & $15 \%$ \\
\hline Group 3 & $14 \%$ & $31 \%$ & $39 \%$ & $15 \%$ \\
\hline Group 4 & $12 \%$ & $28 \%$ & $44 \%$ & $16 \%$ \\
\hline
\end{tabular}


At the initial stage, students had a certain level of knowledge, where the highest number of grades were "good" and "satisfactory". At the final stage, pupils showed an increase in proficiency by an average of $5 \%$. The control work on module 2 showed that all groups showed an increase in the level of mastery of English grammar.

At the final stage, a survey was also conducted among the students to assess the practice of introducing video content to the study of English grammar.

Table 5. Questionnaire to evaluate the effectiveness of introducing video content to English language lessons

\begin{tabular}{|l|l|l|l|l|}
\hline Question & $\mathrm{G} 1$ & $\mathrm{G} 2$ & $\mathrm{G} 3$ & $\mathrm{G} 4$ \\
\hline Learning grammar is a necessary condition for a good level of English & $75 \%$ & $70 \%$ & $73 \%$ & $64 \%$ \\
\hline $\begin{array}{l}\text { You can gain additional knowledge of the language, have more opportunities to learn } \\
\text { complex material }\end{array}$ & $47 \%$ & $33 \%$ & $50 \%$ & $45 \%$ \\
\hline Watching videos in English is a way to increase active communication & $23 \%$ & $27 \%$ & $30 \%$ & $43 \%$ \\
\hline $\begin{array}{l}\text { Movies and shows in English are the best reward and entertainment after a difficult } \\
\text { topic }\end{array}$ & $88 \%$ & $80 \%$ & $72 \%$ & $68 \%$ \\
\hline $\begin{array}{l}\text { The knowledge of grammar has a positive effect on the ability to dialogue, as well as } \\
\text { understand, read and write. }\end{array}$ & $60 \%$ & $49 \%$ & $55 \%$ & $47 \%$ \\
\hline With the introduction of video, grammar topics are learned faster. & $38 \%$ & $43 \%$ & $32 \%$ & $36 \%$ \\
\hline It is worth using the video constantly during the English lessons & $67 \%$ & $53 \%$ & $66 \%$ & $54 \%$ \\
\hline
\end{tabular}

The survey showed that more than $50 \%$ of the students who participated in the experiment want to continue the experience of using video content to study grammar, and the vast majority of respondents (more than $70 \%$ ) consider video to be the best benefit after an important topic.

\section{DISCUSSION}

The issue of introducing audiovisual technology has been considered in a number of pedagogical studies. The focus was often on researching the impact of introducing video content in foreign language lessons, namely the impact of watching authentic English film productions the ability to listen and perceive different English accents. The oral English skills were also improved; also, the researcher pointed out the need for careful selection of video material and special comments on the exercises [20]. In this study, too, in addition to improving student achievement, an important component of the experiment was carefully prepared and clearly shaped curriculum and instructional videos. Working with video content also includes the development of new methods and forms of learning, ways to improve foreign language proficiency [21]. These are repetitions of the way of pronunciation of artists after watching videos, conducting "audio dubbing" by students, based on the developed set of didactic materials [22]. It also raised students' motivation to learn foreign languages as such. In this study, interviews with teachers and surveys of students have shown that there is motivation to learn such a difficult section as grammar, provided the right video content is used. In general, as shown by a number of studies in the introduction to the study of foreign languages audiovisual technology [23] increases students' self-esteem and generally their success. In fact, according to the results of the study, student achievement increased by $5 \%$, more than $70 \%$ of students believe the introduction of video content to the study of English grammar is a good practice.

In the future, it is worth continuing research on the introduction of new ways of introducing audiovisual technology into the educational space, as well as developing practices to increase the pedagogical skills of teachers working in the field of teaching foreign languages.

\section{CONCLUSION}

The research shows that the introduction of English grammar into the learning process is successful. The introduction of video content to learning in general has a positive impact on the success in learning English: it increased on average by $5 \%$. In addition, pupils' perception of the use of video content for studying English grammar improved, almost $70 \%$ wanted to continue this practice permanently. During the interviewing of the teachers, it was found that after participating in the experiment most of them consider it advisable to introduce systematized video content in the process of learning English grammar, in general modern education requires the introduction of new methods of learning foreign languages. At the final stage, the teachers had a clearer and more holistic view on the use of films as teaching material for learning English

This study aimed to find out how willing participants in the educational process were to use video content as a teaching tool. Promoting the adoption of audiovisual technology is challenging because it is not only up to students but also to educators to see the benefits of such innovations and to change personal learning strategies. In addition to the lack of proper methodological training, it is necessary to point out the insufficiency of didactic material - a resource that is designed to aid a student in their learning experience, the main goal of which makes the acquisition of language competence.

Prospects for future research may be to consider audiovisual technology as one that not only improves language proficiency but also raises students' awareness of intercultural, artistic aspects of life in the country of the language studied. 


\section{REFERENCES}

[1] Howlett, G. and Waemusa, Z. (2019). Century learning skills and autonomy: students' perceptions of mobile devices in the THAI EFL context. Teaching English with Technology, vol.19(1), 72-85. Retrieved from URL http://www.tewtjournal.org 7221 st by

[2] Mykytiuk, S., Lysytska, O., Melnikova, T. (2020) Facebook Group as an Educational Platform for Foreign Language Acquisition. Postmodern Openings, vol. 11, Issue 1, Supl. 1, 131-157. https:// doi.org/10.18662/po/11.1sup1/127

[3] Hortigüela-Alcalá, D., Sánchez-Santamaría, J., PérezPueyo, A., \& Abella-García, V. (2019). Social networks to promote motivation and learning in higher education from the students' perspective. Innovations in Education and Teaching International, vol. 56(4), 412-422. https://doi.org/10.1080/14703297.2019.1579665

[4] Ruey, S., Kun, L. (2014). Using films to teach speaking in the ESL classroom: A case study. UNISEL Journal of Social Sciences and Humanities, vol. 1(1), 50-56.

[5] Jurkovič, V., Mertelj, D. (2015). Pedagogical uses of authentic video in ESP classrooms for developing language skills and enriching vocabulary. Scripta Manent, vol. 9(2), 15-33. Retrieved from URL https://scriptamanent.sdutsj.edus.si/ScriptaM anent/article/view/126/112

[6] Hobbs, R. (2006). Non- optimal uses of video in the classroom. Learning, Media and Technology, vol. 31(1), 35-50. https://doi.org/10.1080/17439880500515457

[7] Karpushyna, M., Bloshchynskyi, I., Nakonechna, A., \& Skyba, K. (2019). Creating meaningful foreign language environment by means of content-based starters. Universal Journal of Educational Research, vol. 7(12), 2710 2716. Retrieved from

URL https://doi.org/10.13189/ujer.2019.071219

[8] Stewart, D. M. (2006). Film English: Using films to teach English. Electronic Journal of English Education, vol. 24, 1-17. http://english.ncu.edu.tw/Stewart/Research/Fil m\%20English.pdf

[9]Ahmad, M. (2016). Using Facebook to develop grammar discussion and writing skills in English as a foreign language for university students. Sino-us English Teaching, vol. 8(12), 932-952. Retrieved from URL https:// doi.org/10.17265/1539- 8072/2016.12.004

[10] Fritz, W., Mollenberg, A., \& Chen, G. M. (2002). Measuring intercultural sensitivity in a different cultural context. Intercultural Communication Studies, vol.11 (2), 165-176. Retrieved from: https://web.uri.edu/iaics/files/12Wolfgang-Fritz-Antje-Mollenberg.pdf

[11] Dizon, G. (2018). Quizlet in the EFL classroom: Enhancing academic vocabulary acquisition of Japanese university students. Teaching English with Technology, vol. 16(2), 40-56. Retrieved from URL https:// doi.org/10.31235/osf.io/rkpvg

[12] Rababah, I. (2020). The Reality of Using Modern Teaching Methods in Teaching Arabic for Speakers of other Languages from Teachers' Perspective. Journal of
Social Sciences, Retrieved from URL https:// doi.org/10.25255/jss.2020.9.1.58.94

[13] Köktürk, Ş. (2012). Forms and Multifunctionality of Interruptions and Simultaneous Speaking in Ordinary Talk - proposal of a Universal Model for the Evaluation of Interruptive Speech Sequences. International Journal of Linguistics, vol. 4, No. 3, 551- 571. https:// doi:10.5296/ijl.v4i3.2137 U

[14] Cavus, N. and Ibrahim, D. (2017) Learning English Using Children's Stories in Mobile Devices. British Journal of Educational Technology, vol. 48, 625-641. Retrieved from URL https:// doi.org/10.1111/bjet.12427

[15] Dzvinchuk, D., Radchenko, O., Kachmar, O., Myskiv, I., Dolinska, N. (2020). Analysis of Platforms and Tools of Open Study in the Conditions of Postmodern Education. Revista Romaneasca Pentru Educatie Multidimensionala, vol. 12(3), 125-143. https://doi.org/10.18662/rrem/12.3/313

[16] Voinea, M. (2012). The role of intercultural education in defining the system of individual values. Procedia - Social and Behavioral Sciences, vol. 33, 288292. https://doi.org/10.1016/j.sbspro.2012.01.129

[17] Veera, I, Pietilä,_P. (2018). Multilingualism as a resource in the foreign language classroom. ELT Journal, vol. 72, Issue 3, 237-248. Retrieved from URL https:// doi.org/10.1093/elt/ccx073

[18] Mason, R. (2006). Learning technologies for adult continuing education. Studies in Continuing Education, 28(2), 121-133. https://doi.org/10.1080/01580370600751039

[19] Canning-Wilson, C. (2000). Practical aspects of using video in the foreign language classroom. The Internet TESL Journal, 6(11). Retrieved from URL http://iteslj.org/Articles/Canning-Video.html

[20] Kaiser, M. (2011). New approaches to exploiting film in the foreign language classroom. L2 Journal, 3(2), 232-249.

[21] Čhlová, R. (2019). Intercultural Adaptation Process and Its Determinants. International Journal of Economics, Finance and Management Sciences, vol. 7(6), 215-221. https:// doi: http://www.sciencepublishinggroup.com/journal/paper info?journalid $=173 \&$ doi $=10.11648 /$ j.jefm. 20190706.16

[22] Sánchez-Auñón, E. Férez-Mora, P. (2021). Films for EFL: Exploring the perceptions of a high school teacher. Indonesian Journal Of Applied Linguistics. vol. 11 No. 1, 49-59 https://doi.org/10.17509/ijal.v11i1.34634

[23] Pisarenko, V. (2017). Teaching a foreign language using videos. Social Sciences, vol. 6(4), 125-146. https://doi.org/10.3390/socsci6040125

\section{Creative Commons Attribution License 4.0 (Attribution 4.0 International, CC BY 4.0)}

This article is published under the terms of the Creative Commons Attribution License 4.0 https://creativecommons.org/licenses/by/4.0/deed.en_US 